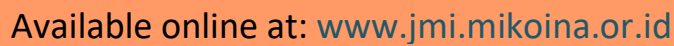

\section{Pemanfaatan Kapang Rhizopus sp. sebagai Agen Hayati Pengapung Pakan Ikan}

\section{Utilisation of the Fungus Rhizopus sp. as Bio-Floating Agent in Fish Feed}

\author{
Sriherwanto $\mathbf{C}^{1 *}$, Suja'i $\mathbf{I}^{1}$, Soraya ${ }^{2}$ \\ ${ }^{1}$ Balai Bioteknologi, Badan Pengkajian dan Penerapan Teknologi, Gedung 630, Kawasan Puspiptek, Tangerang \\ Selatan, Banten 15314, Indonesia. Email: catur.sriherwanto@bppt.go.id \\ ${ }^{2}$ Fakultas Teknologi Pertanian, Jln. Raya Olat Maras, Moyo Hulu, Sumbawa, Nusa Tenggara Barat 84371, \\ Indonesia
}

Sriherwanto C, Suja'i I, Soraya. 2017 - Pemanfaatan Kapang Rhizopus sp. sebagai Agen Hayati Pengapung Pakan Ikan 1(2), 70-81

\begin{abstract}
Abstrak
Rhizopus sp. dikenal sebagai kapang tempe kedelai, dan juga banyak digunakan dalam fermentasi substrat selain kedelai. Aktivitas metabolisme Rhizopus sp. memberikan sifat fisik baru pada substrat yang difermentasi, termasuk kemampuan mengapung pada permukaan air dan kekompakan dalam air karena miselianya merajut dan menyatukan butiran-butiran substrat. Sifat ini berpotensi diterapkan dalam pembuatan pakan ikan apung. Dalam penelitian ini, Rhizopus sp. digunakan sebagai agen pengapung hayati pada pakan ikan melalui fermentasi padat dimana pakan ikan tenggelam komersial digunakan sebagai substrat. Pakan fermentasi yang dihasilkan lalu dikeringkan di dalam oven dan diuji untuk mengetahui kualitas fisiknya dibandingkan dengan pakan ikan apung komersial (kontrol positif). Hasil penelitian menunjukkan bahwa baik pakan ikan apung fermentasi dan pakan ikan apung komersial memiliki daya apung $\geq 95 \%$ selama 60 menit, dengan stabilitas dalam air tanpa aerasi masingmasing 80,3-87,1\% dan 85,6\%. Namun, dalam air beraerasi, daya apung pakan fermentasi menurun menjadi 0-2,5\%, sedangkan pada pakan kontrol 82,5\%. Daya serap air pakan fermentasi berkisar antara $108 \%$ sampai $144 \%$, yakni lebih rendah dari pada pakan komersial (260\%). Dapat disimpulkan bahwa fermentasi padat menggunakan Rhizopus sp. berpotensi dikembangkan lebih lanjut sebagai agen pengapung hayati dalam pembuatan pakan ikan apung.
\end{abstract}

Katakunci - daya apung - daya serap air - fermentasi- kehilangan bobot kering - stabilitas dalam air

\begin{abstract}
Rhizopus sp. is known as the soybean tempeh fungus, and is also widely used in fermentation of substrates other than soybean. Metabolic activities of Rhizopus sp. confer novel physical properties to the fermented substrate, including the ability to float on water and water stability due to mycelia knitting the substrate particles together. These characteristics could potentially be applied in preparing floating aquafeed. In this study, Rhizopus sp. was used as bio-floating agent in fish feed through solid state fermentation in which commercial sinking fish feed was used as the substrate. The resulted fermented feed was oven-dried and subjected to a number of
\end{abstract}


tests to determine its physical quality compared to the commercial floating fish feed (positive control). The results showed that both the fermented and commercial floating feeds possessed $\geq 95 \%$ buoyancy for 60 minutes, with water stability in unaerated water of 80.3-87.1\% and $85.6 \%$, respectively. In aerated water, however, fermented feed floatability declined to $0-2.5 \%$, whereas the control feed $82.5 \%$. Water absorption capacity of the fermented feed ranged from $108 \%$ to $144 \%$, which was lower than that of the commercial feed (260\%). Thus, Rhizopus sp. solid state fermentation has a potential to be further developed as bio-floating agent in the production of floating fish feed.

Key words - dry matter loss - fermentation - floatability - water absorption - water stability

\section{Pendahuluan}

Rhizopus sp. merupakan kapang filamen dari kelas Zygomycetes yang dikenal sebagai jamur tempe kedelai yang merupakan makanan fermentasi khas asal Indonesia. Selain kedelai, saat ini, Rhizopus sp. juga telah dikembangkan di negara lain dalam fermentasi menggunakan substrat bahan pangan non-kedelai seperti kacang polong liar (Niveditha \& Sridhar 2014), soba (Wronkowska et al. 2015), jelai (Sandhu \& Punia 2017), kacang rumput (Starzyńska-Janiszewska et al. 2015), dan kacang lupin (Priatni et al. 2013).

Pengaruh Rhizopus sp. pada substrat yang difermentasinya juga telah diteliti dari segi karakteristik fisiknya seperti modulus elastisitas (Handoyo \& Morita 2006), maupun kemampuan mengembang, daya larut, kapasitas serap air, dan kapasitas ikat air (Olanipekun et al. 2009). Fermentasi menggunakan Rhizopus sp. juga memunculkan daya apung positif pada substrat hasil fermentasi (Umam et al. 2015; Pradana et al. 2017), yang dapat diterapkan, misalnya, dalam pembuatan pakan ikan apung. Sifat apung pada pakan ikan memudahkan dalam mengetahui kebutuhan pakan ikan saat pemberian pakan. Pakan yang berlebihan dan tidak seluruhnya dikonsumsi ikan akan diurai oleh bakteri heterotrofik yang memerlukan konsumsi oksigen dalam air. Penguraian pakan yang tersisa ini juga meningkatkan kandungan nitrit dan amonia hingga tingkat yang dapat meracuni ikan dalam waktu singkat (Somerville et al. 2014).

Penelitian ini bertujuan untuk mengetahui potensi kapang Rhizopus sp. sebagai agen hayati pengapung pakan ikan melalui fermentasi padat menggunakan substrat berupa pakan ikan tenggelam komersial. Diharapkan melalui penelitian ini dapat dikembangkan metode alternatif pengapungan pakan yang lebih mudah, murah, dan praktis dibandingkan penggunaan mesin pengapung pakan ikan (mesin ekstruder) yang harga belinya mahal, memerlukan biaya operasional tinggi, serta memerlukan ketrampilan tambahan dalam proses produksinya (FAO 2017).

\section{Metoda Penelitian \\ Desain Penelitian}

Penelitian ini menggunakan metode eksperimental menggunakan 3 jenis sampel pakan ikan yang berbeda, yakni pakan tenggelam komersial (tanpa fermentasi, kontrol negatif), pakan tenggelam komersial yang telah difermetasi (pakan fermentasi), dan pakan apung komersial (kontrol positif). Khusus untuk sampel pakan yang difermentasi, terdapat 6 perlakuan waktu perendaman air yang berbeda sebelum proses fermentasi pada substrat pakan tenggelam komersial. Ketiga jenis sampel tersebut kemudian diuji beberapa kualitas fisiknya untuk kemudian dibandingkan. Masing-masing perlakuan fermentasi dan pengujian dilakukan sebanyak 2 kali ulangan (duplo). 
Tabel 1 Komposisi nutrisi pakan tenggelam komersial Buana Mas dan pakan apung komersial Global Neo

\begin{tabular}{llcc}
\hline No & Nutrisi (\%) & $\begin{array}{c}\text { Pakan apung komersial } \\
\text { merek Global Neo }\end{array}$ & $\begin{array}{c}\text { Pakan tenggelam komersial } \\
\text { merek Buana Mas (Nurlaila 2016) }\end{array}$ \\
\hline 1 & Air & maks. 12 & 8,18 \\
2 & Abu & maks. 13 & 28,01 \\
3 & Serat kasar & maks. 8 & 0,76 \\
4 & Lemak & min. 5 & 6,62 \\
5 & Protein & min. 14-16 & 29,75 \\
6 & Karbohidrat & tidak tercantum & 34,85 \\
\hline
\end{tabular}

\section{Fermentasi pakan}

Seluruh proses fermentasi dilakukan dalam keadaan tidak steril dan tanpa sterilisasi. Ke dalam gelas beaker $250 \mathrm{~mL}$ (Schott Duran, Jerman) yang sudah diisi $50 \mathrm{~g}$ substrat pakan tenggelam komersial (Buana Mas, PT. Balqis Sejahtera, Bandung Barat), dengan kandungan nutrisi yang telah dianalisa sebelumnya (Nurlaila 2016) (Tabel 1), ditambahkan air kran 50 $\mathrm{mL}$, dibiarkan terendam dengan lama waktu yang berbeda (6 perlakuan), yakni selama 0,5 , 10, 15, 30, 45 dan 60 menit. Substrat basah tersebut kemudian dicampur dengan inokulum ragi tempe Rhizopus sp. $1 \mathrm{~g}\left(6,17 \times 10^{6} \mathrm{cfu} / \mathrm{g}\right)$ yang dibeli dari pengusaha tempe lokal di kelurahan Serpong, kecamatan Serpong, Tangerang Selatan, Banten. Setelah diaduk rata, substrat dimasukkan ke dalam cawan petri berdiameter $9 \mathrm{~cm}$ (Anumbra), dan diinkubasi pada suhu ruangan $\left(29 \pm 1^{\circ} \mathrm{C}\right)$ selama $24 \mathrm{jam}$. Setelah itu, pakan fermentasi dikeringkan di dalam oven (Memmert, 100-800) bersuhu $50^{\circ} \mathrm{C}$ selama 24 jam, ditumbuk dengan mortar, dan diayak menggunakan saringan bertingkat dengan ukuran lubang berdiameter 7 dan $6 \mathrm{~mm}$ untuk mendapatkan ukuran pelet antara 6 dan $7 \mathrm{~mm}$. Pakan fermentasi ini, bersama dengan pakan tenggelam dan pakan apung komersial (merk Global Neo, PT. Luxindo Internusa, Bekasi) (Tabel 1) lalu diuji kualitas fisiknya yang meliputi: kehilangan berat kering selama fermentasi (dry matter loss), daya apung (floatability atau buoyancy), daya serap air (water absorption), dan stabilitas dalam air (water stability).

\section{Kehilangan bobot kering}

Perhitungan kehilangan bobot kering menggunakan metode penimbangan, dimana berat kering substrat hasil fermentasi pasca pengovenan dibandingkan dengan berat kering sebelum fermentasi:

$$
\text { kehilangan bobot kering }(\%)=\frac{\text { berat kering substrat hasil fermentasi }(g)}{\text { berat kering substrat sebelum fermentasi }(g)} \times 100 \%
$$

\section{Daya serap air}

Sebanyak 1-1,5 g pelet ditimbang menggunakan timbangan analitik (Ohaus, Pioneer, PA214, USA), lalu dimasukkan ke dalam saringan plastik teh dengan ukuran \pm 200 mesh (Erizal et al. 2016), selanjutnya direndam dalam air menggunakan beaker glass $500 \mathrm{~mL}$ (Pyrex, Iwaki TE-32, Jepang) dan diaerasi maksimum 3,5L/menit menggunakan aerator akuarium (Luckiness, L828, Cina). Pada menit ke-1, 3, 5, 10, 20 dan 40 sampel diangkat dan ditiriskan, lalu ditimbang dalam keadaan basah. Daya serap atau absorpsi air dihitung dengan menggunakan rumus (Misra et al. 2002):

$$
\text { absorpsi air }(\%)=\frac{\text { berat basah pasca perendaman }(g)-\text { berat kering awal }(g)}{\text { berat kering awal }(g)} \times 100 \%
$$




\section{Daya apung}

Pengukuran daya apung dilakukan dua kali dengan dua cara yang berbeda yaitu dengan dan tanpa aerasi. Pengukuran dengan dua cara ini untuk mengetahui kemampuan pakan untuk tetap mengapung pada kondisi kolam yang tenang dan yang bergelombang. Daya apung dengan aerasi dilakukan selama 1 jam dengan menjatuhkan 20 butir pakan ke dalam gelas beaker $500 \mathrm{~mL}$ yang berisi air $400 \mathrm{~mL}$ dengan gelembung udara dari aerator. Daya apung tanpa aerasi dilakukan dengan menjatuhkan 10 butir pakan ke dalam gelas beaker $500 \mathrm{~mL}$ yang berisi air $400 \mathrm{ml}$ tanpa gelembung udara. Jumlah butir pakan yang masih mengapung dicatat pada interval menit tertentu selama 60 menit. Daya apung dihitung dengan menggunakan rumus berikut:

$$
\text { dayaapung }(\%)=\frac{\text { jumlah butir pakan yang masih mengapung }}{\text { jumlah awal butir pakan }} \times 100 \%
$$

\section{Stabilitas dalam air}

Pengukuran ini mengikuti metode sebelumnya (Misra et al. 2002) yang telah dimodifikasi, dimana 1-1,5 g pelet diletakkan dalam saringan plastik teh lalu direndam dalam gelas beaker yang telah berisi air $500 \mathrm{~mL}$ dan diaerasi menggunakan aerator selama 40 menit. Selanjutnya, sisa butiran pakan yang tidak hancur dan telah menyerap air ditiriskan, lalu dikeringkan dalam oven selama $19 \mathrm{jam}$ pada suhu $50^{\circ} \mathrm{C}$. Stabilitas dalam air dihitung dengan rumus:

$$
\text { stabilitas dalam air }(\%)=\frac{\text { berat kering pasca perendaman dalam air }(\mathrm{g})}{\text { berat kering sebelum perendaman dalam air }(\mathrm{g})} \times 100 \%
$$

\section{Hasil \\ Fermentasi pakan}

Setelah 24 jam fermentasi, substrat pakan tenggelam komersial yang awalnya bertekstur granul atau butiran-butiran terpisah berwarna coklat berubah menjadi satu wujud padat layaknya tempe dengan permukaan berwarna putih kapas keabu-abuan. Tidak lagi terlihat granul coklat yang terpisah, karena rongga antar-granul dipenuhi oleh miselia bertekstur seperti kapas yang lebat dan padat, yang mengikat dan menyatukan butiran-butiran pakan menjadi satu kesatuan (Gambar 1). Terlihat air mengembun pada permukaan bagian dalam tutup cawan metri yang merupakan indikasi adanya uap air yang dilepaskan sebagai produk metabolisme oleh kapang. Setelah dikeringkan, ditumbuk, dan disaring, didapatkan butiran atau granul pakan fermentasi dengan bentuk yang kurang seragam dibandingkan pakan tenggelam dan pakan apung komersial, namun pakan fermentasi ini sudah memiliki sifat mengapung, berbeda dari substrat aslinya yang tenggelam (Gambar 2).

\section{Kehilangan bobot kering}

Kehilangan bobot kering substrat akibat fermentasi berkisar antara 16-24\% dengan ratarata 19,3 $\pm 2,6 \%$, atau sekitar seperlima dari massa awal pakan komersial tenggelam yang hilang selama fermentasi. Berdasarkan data ini, dan data massa jenis pakan tenggelam komersial 1,14 $\mathrm{g} \cdot \mathrm{cm}^{-3}$ (data tak terpublikasi), dapat dihitung secara matematis bahwa nilai massa jenis pakan ini setelah difermentasi adalah prosentase bobot kering yang tersisa dikalikan massa jenis awal sebelum fermentasi, yakni $80,7 \pm 2,6 \% \times 1,14=0,92 \pm 0,03 \mathrm{~g} \cdot \mathrm{cm}^{-3}$. Massa jenis sesungguhnya mungkin lebih rendah dari nilai tersebut mengingat rongga kosong antar butiran substrat yang terisi oleh miselia tidaklah dimasukkan dalam perhitungan matematis tersebut. Terlepas dari itu, nilai massa jenis yang lebih rendah daripada $1 \mathrm{~g} \cdot \mathrm{cm}^{-3}$ (massa jenis air) ini menjelaskan mengapa pakan fermentasi mengapung pada permukaan air (Gambar 2). 

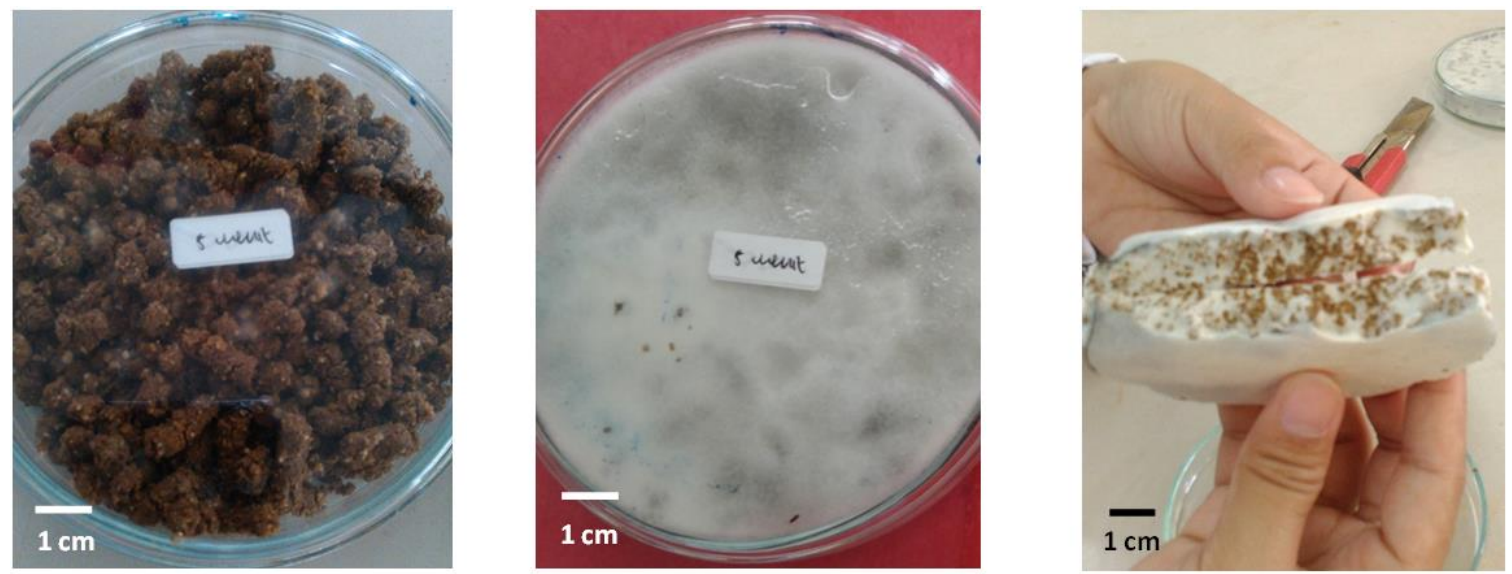

Gambar 1. Substrat pakan tenggelam komersial yang telah direndam air dan dicampur inokulum sebelum (kiri) dan sesudah fermentasi 24 jam oleh Rhizopus. sp. (tengah), dan penampang irisan melintangnya (kanan)
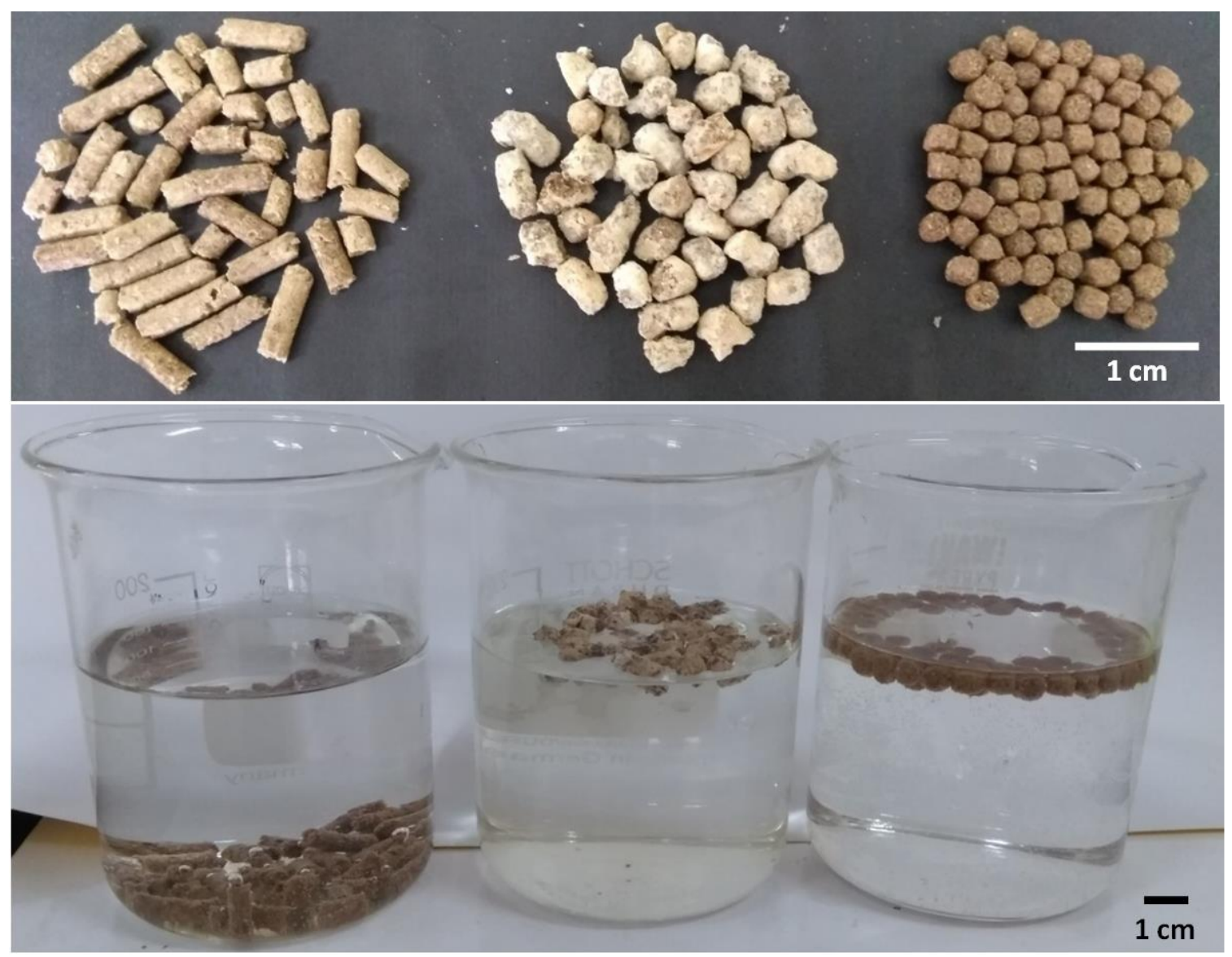

Gambar 2. Pakan tenggelam komersial (kiri), pakan apung fermentasi (tengah), dan pakan apung komersial (kanan)

\section{Daya serap air}

Pakan tenggelam komersial memiliki daya serap air terendah dibandingkan seluruh pakan jenis lainnya (Gambar 3), yakni kurang dari 80\%. Ini mengisyaratkan kepadatan butiran tepung penyusun pakan dan minimnya rongga udara mikro sehingga tidak memungkinkan banyak ruang bagi penyerapan air. Pakan apung fermentasi memiliki daya serap air pada kisaran 108-144\%, sekitar setengah dari nilai daya serap air pakan apung 
komersial (260\%). Perendaman selama 5 menit menghasilkan profil absorpsi air pakan apung fermentasi (PAF-5) yang menyerupai pakan apung komersial, yakni lonjakan tajam prosentasi air yang terserap sejak di menit ke-1 perendaman. Pakan apung komersial memiliki daya serap air tertinggi, yakni hingga melebihi 2 kali lipat bobot keringnya.

\section{Daya apung}

Daya apung pakan dengan dan tanpa aerasi memperlihatkan profil yang berbeda, terutama pada pakan apung fermentasi (Gambar 4). Tanpa aerasi, semua pakan apung fermentasi memiliki daya apung 100\%, dengan kata lain mengapung terus selama pengujian, tak satu pun tenggelam, sehingga grafik garisnya tumpang tindih satu sama lain. Pakan apung komersial 95\% mengapung stabil hingga menit ke-60, sedangkan pakan tenggelam tidak mengapung sama sekali sejak awal. Uji apung tanpa aerasi ini dilanjutkan hingga keesokan harinya, yakni hingga jam ke-18 untuk pakan apung fermentasi dan hingga jam ke-20 untuk pakan apung komersial. Hasilnya, pakan apung fermentasi masih 100\% mengapung, sedangkan pakan apung komersial seluruhnya tenggelam. Profil yang berbeda ditunjukkan oleh hasil uji daya apung dengan aerasi, dimana pakan apung fermentasi hampir semuanya (0-2,5\%) tenggelam di menit ke-60 (Gambar 5). Pakan apung komersial 82,5\% mengapung stabil hingga menit ke-60, sedangkan pakan tenggelam tidak mengapung sama sekali.

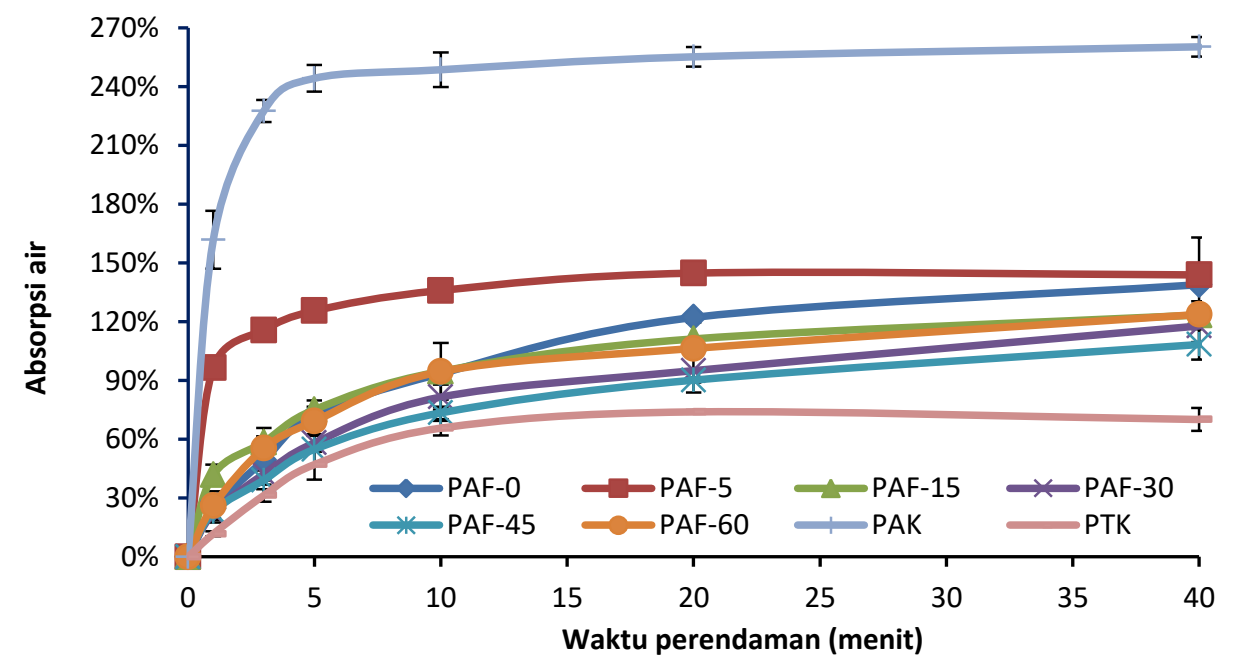

Gambar 3. Absorpsi air pakan tenggelam komersial (PTK), pakan apung komersial (PAK), dan pakan apung fermentasi yang didahului dengan perendaman substrat selama 0 menit (PAF-0), 5 menit (PAF-5), 15 menit (PAF-15), 30 menit (PAF-30), 45 menit (PAF-45), dan 60 menit (PAF-60)

\section{Stabilitas dalam air}

Stabilitas, kekokohan, keutuhan, atau kekompakan dalam air merupakan parameter untuk mengetahui mudah tidaknya pakan ikan mengalami kehancuran saat berada di dalam air. Nilai stabilitas dalam air merupakan prosentase massa yang tidak hancur, semakin stabil pakan maka nilai stabilitasnya dalam air akan semakin mendekati $100 \%$. Pakan tenggelam komersial terbukti paling rendah nilai stabilitas airnya $(63,2 \%)$, tidak kompak, paling mudah hancur (Gambar 6). Namun, substrat pakan tenggelam komersial tersebut setelah difermentasi menggunakan kapang Rhizopus sp. menghasilkan pakan apung fermentasi dengan stabilitas dalam air yang lebih baik, yakni 80,3-87,1\%, setara dengan pakan apung komersial $(85,6 \%)$. 


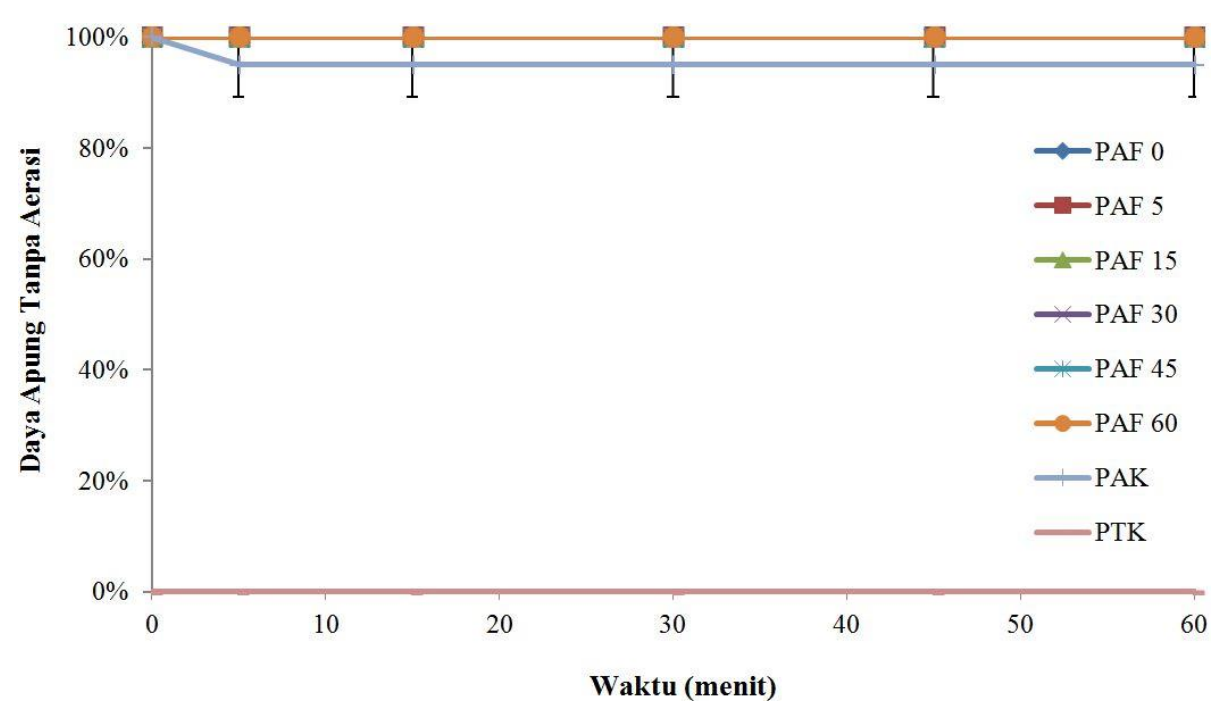

Gambar 4. Daya apung dalam air tanpa aerasi dari pakan tenggelam komersial (PTK), pakan apung komersial (PAK), dan pakan apung fermentasi yang didahului dengan perendaman substrat selama 0 menit (PAF-0), 5 menit (PAF-5), 15 menit (PAF-15), 30 menit (PAF-30), 45 menit (PAF-45), dan 60 menit (PAF-60)

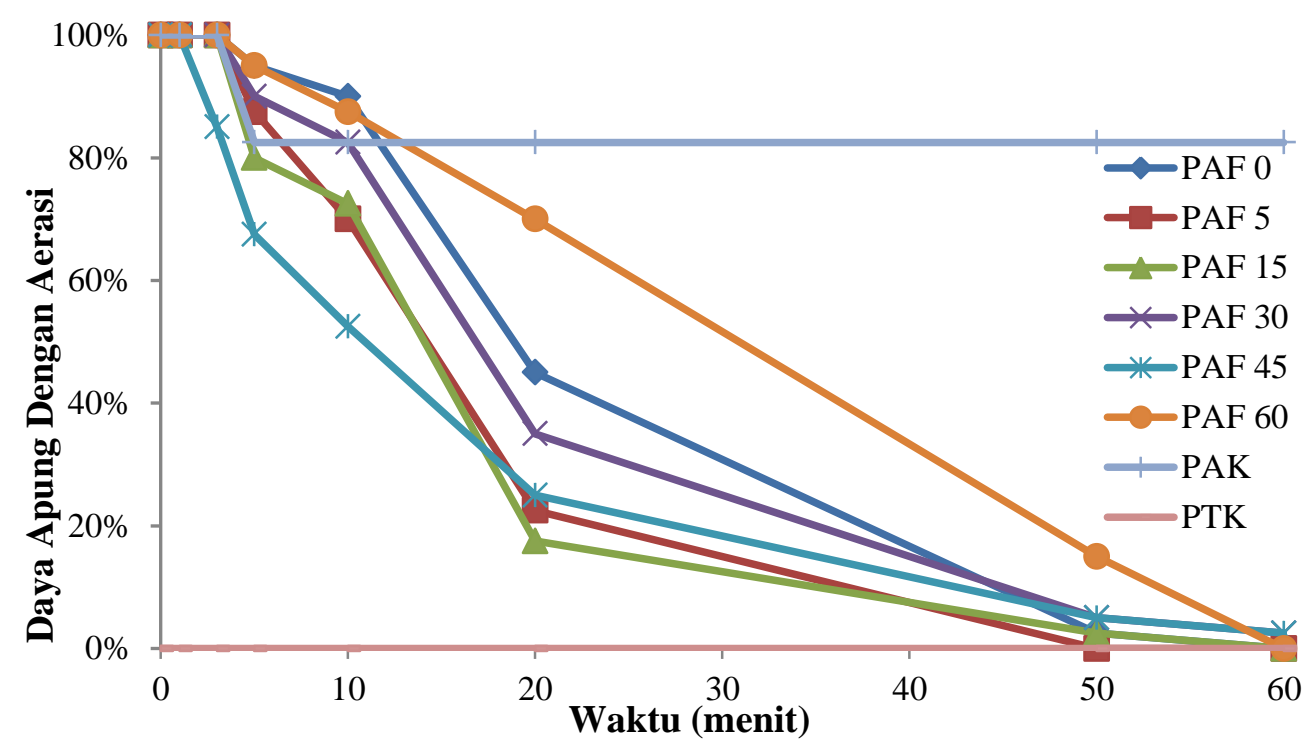

Gambar 5. Daya apung dalam air dengan aerasi dari pakan tenggelam komersial (PTK), pakan apung komersial (PAK), dan pakan apung fermentasi yang didahului dengan perendaman substrat selama 0 menit (PAF-0), 5 menit (PAF-5), 15 menit (PAF-15), 30 menit (PAF-30), 45 menit (PAF-45), dan 60 menit (PAF-60)

Ketika stabilitas dalam air ini dihubungkan dengan daya serap air mutlak (dengan faktor pembagi berat kering awal pakan di menit ke-0) dan daya serap air relatif (dengan faktor pembagi berat kering pakan di menit ke-40), maka terlihat bahwa stabilitas menentukan daya serap. Namun terdapat perbedaan sangat ekstrim antara stabilitas dalam air dan daya serap air pada pakan apung komersial, meskipun memiliki nilai stabilitas air yang relatif sama dengan pakan fermentasi. Ini menunjukkan secara umum materil pakan apung fermentasi memiliki kemampuan mengikat air yang lebih rendah dibandingkan material pakan apung komersial. 


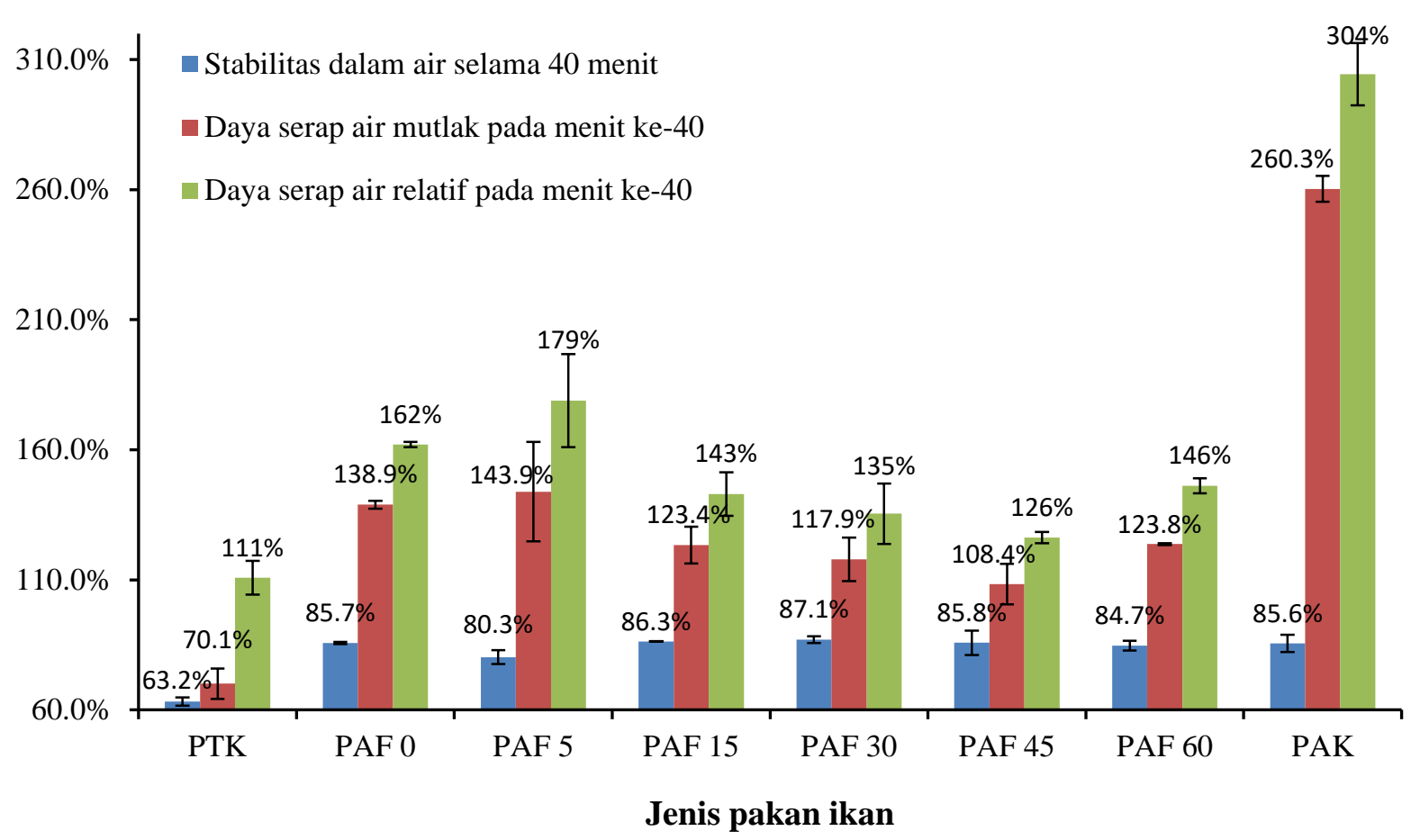

Gambar 6. Hasil pengukuran uji stabilitas air dan daya serap air pada menit ke-40 dari pakan tenggelam komersial (PTK), pakan apung komersial (PAK), dan pakan apung fermentasi yang didahului dengan perendaman substrat selama 0 menit (PAF-0), 5 menit (PAF-5), 15 menit (PAF-15), 30 menit (PAF-30), 45 menit (PAF-45), dan 60 menit (PAF-60)

\section{Pembahasan}

Selama ini, penggunaan Rhizopus sp. dalam pakan telah banyak diteliti, baik sebagai agen fermentasi untuk memperbaiki kualitas nutrisi bahan pakan (Umam et al. 2015; Kurniati et al. 2017; Valdez-González et al. 2017), maupun sebagai biomassa atau komponen bahan pakan kaya nutrisi, khususnya protein (Ferreira et al. 2013; Abro et al. 2014a; Abro et al. 2014b; Langeland et al. 2016; Satari et al. 2016; Vidakovic et al. 2016; FazeliNejad et al. 2016; Souza Filho et al. 2017). Akan tetapi pemanfaatan kapang tersebut untuk memperbaiki kualitas fisik pakan ikan, terutama daya apung dan stabilitas dalam air, belum banyak dilakukan.

Pakan ikan yang awalnya tenggelam dapat memiliki sifat mengapung dan tidak mudah hancur dalam air setelah difermentasi menggunakan kapang filamen Rhizopus sp. Sifat mengapung ini muncul pada substrat yang difermentasi asalkan kapang Rhizopus sp. tumbuh dengan baik pada substrat tersebut, yang dibuktikan dengan pembentukan miselia padat lebat seperti kapas yang menyatukan butiran-butiran substrat dan memenuhi sela-sela antar-butiran substrat. Kekuatan miselia Rhizopus sp. dalam menjalin substrat telah diteliti sebelumnya menggunakan substrat kedelai, dimana tempe yang mengalami fermentasi 48 jam mempunyai tingkat kelemahan $(7,14 \mathrm{~N})$, modulus elastisitas $\left(1,02 \times 10^{9} \mathrm{~Pa}\right)$, dan titik luluh $\left(8,17 \times 10^{6}\right.$ $\mathrm{Pa}$ ). Nilai ketiga parameter ini melebihi tempe yang difermentasi selama 24 dan 72 jam (Handoyo \& Morita 2006).

Sifat apung ini tidak tergantung pada substrat yang difermentasi. Penelitian sebelumnya tentang pakan buatan untuk ikan mas yang menggunakan campuran dedak padi dan ampas kelapa parut sebagai substrat dan Rhizopus oryzae sebagai agen fermentasi mampu menghasilkan pakan ikan buatan yang mengapung dalam air (Umam et al. 2015). Formulasi pakan ikan nila menggunakan kombinasi kulit daging buah kelapa dan tepung onggok singkong yang difermentasi Rhizopus oryzae juga memunculkan sifat apung pada pakan hasil 
fermentasi (Pradana et al. 2017). Namun kedua penelitian fermentasi pakan ikan tersebut belum melaporkan secara kuantitatif hasil pengukuran karakteristik fisiknya seperti daya apung, stabilitas dalam air, daya serap air, maupun parameter fisik lain yang perlu dimiliki oleh pakan ikan apung.

Daya apung dalam penelitian ini diukur dengan dan tanpa aerasi. Aerasi berpengaruh terhadap kemampuan daya apung pakan fermentasi, di mana terjadi pertambahan jumlah pakan yang tenggelam seiring dengan waktu. Aerasi ini memunculkan riak dan gelombang air yang diduga meningkatkan frekuensi benturan antara air dengan pakan. Benturan ini melemahkan struktur miselia jamur, sehingga mempermudah air terserap dan memenuhi sebagian besar ruang-ruang udara mikro pakan fermentasi. Akibatnya, massa jenis total pakan fermentasi yang sudah basah menyerap air ini menjadi lebih besar daripada massa jenis air, sehingga tenggelam. Sebagian besar pakan apung komersial tetap mengapung dikarenakan kemampuannya menahan air agar tidak terserap memasuki ruang-ruang udara mikro di dalamnya. Ini berarti kualitas lapisan miselia Rhizopus sp. yang menyelimuti pakan apung fermentasi belumlah sebaik pada pakan apung komersial, yang menggunakan lemak atau minyak sebagai coating (teknik pelapisan permukaan) pada pelet (Bouvier \& Brisset 2006).

Daya apung dalam air tenang tanpa aerasi dari pakan hasil fermentasi menggunakan kapang Rhizopus sp. dalam penelitian ini lebih baik dibandingkan hasil penelitian sebelumnya. Pengapungan pakan ikan menggunakan bahan pengembang roti (baking powder dan yeast) telah dilaporkan, dengan daya apung maksimal 70\% pada menit ke-60 (Adekunle et al. 2012). Penggunaan kombinasi dedak gandum dan ragi roti (baker's yeast) berhasil mengapungkan pelet hingga 16,7\% selama 20 menit (Momoh et al. 2016). Pelet apung fermentasi menggunakan kapang Aspergillus niger mampu mengapungkan pakan ikan selama 30-45 menit dengan daya tahan dalam air 90\% selama 60 menit (Sutikno et al. 2011).

Dalam penelitian ini, fermentasi mengunakan Rhizopus sp. telah dibuktikan mampu berfungsi sebagai agen pengikat butiran-butiran pakan, sekaligus agen pengapung. Daya ikat miselia Rhizopus sp. terlihat pada stabilitas dalam air yang dimunculkan pada pakan apung fermentasi, di mana nilainya sebanding dengan pakan apung komersial kontrol maupun pakan uji yang dibuat menggunakan mesin pelet uap dengan campuran ragi Saccharomyces cerevisiae (Solomon et al. 2011). Pada penelitian tersebut, ragi yang dikombinasikan dengan tepung tapioka dan maizena secara terpisah memiliki stabilitas hanya $58 \%$ dan $57 \%$ dalam waktu 50 menit dalam air. Ini berarti, hampir separuh dari bahan pakan yang ada hancur dalam air. Hal ini menunjukkan bahwa miselia Rhizopus sp. mampu berfungsi sebagai bahan pengikat (binding agent) dengan kualitas yang tidak kalah dengan zat pengikat konvensional seperti pati (Bouvier \& Brisset 2006) atau biopolimer lain yang biasa digunakan dalam pembuatan pakan akuakultur seperti agar-agar, alginat, pektin, kitosan, karaginan, karboksimetilselulosa, guar gum, dan gelatin (Paolucci et al. 2012). Akan tetapi, meskipun penggunaan Rhizopus sp. sebagai bahan pengikat menunjukkan keberhasilan, masih perlu diteliti kemungkinan ada tidaknya kerugian dalam hal nutrient leaching (hilangnya sebagian nutrisi karena larut dalam air) saat pemberian pakan, dampaknya pada enzim-enzim pencernaan, kecernaan, serta pertumbuhan hewan pengonsumsi.

Sebagai kesimpulan dapat diyatakan bahwa pakan tenggelam komersial, yang awalnya tenggelam dan mudah hancur dalam air, setelah difermentasi menggunakan kapang Rhizopus sp. memiliki sifat apung dan stabilitas dalam air yang baik. Hasil pengukuran karakteristik fisik bahkan menunjukkan bahwa kualitas pakan apung fermentasi ini sebanding dengan pakan apung komersial, terutama stabilitasnya dalam air. Fermentasi padat menggunakan Rhizopus sp. berpotensi untuk dikembangkan lebih lanjut sebagai agen pengapung hayati dalam produksi pakan apung yang lebih murah, praktis, dan ramah lingkungan tanpa perlu 
menggunakan mesin ekstruder yang biaya pembeliannya mahal dan memerlukan keahlian khusus.

\section{Ucapan Terima Kasih}

Terima kasih diucapkan kepada Balai Bioteknologi, BPPT, Kawasan PUSPIPTEK, Tangerang Selatan, atas segala dukungan dana dan sarananya dalam penelitian ini dari awal hingga akhir.

\section{Pustaka}

Abro R, Moazzami AA, Lindberg JE, Lundh T. 2014a- Metabolic insights in Arctic charr (Salvelinus alpinus) fed with zygomycetes and fish meal diets as assessed in liver using nuclear magnetic resonance (NMR) spectroscopy. International Aquatic Research 6, 63.

Abro R, Sundell K, Sandblom E, Sundh H, Brännäs E, Kiessling A, Lindberg JE, Lundh T. 2014b-Evaluation of chitinolytic activities and membrane integrity in gut tissues of Arctic charr (Salvelinus alpinus) fed fish meal and zygomycete biomass. Comp Biochem Physiol Part B Biochemistry\&Molecular Biolology 175, 1-8. doi: https://doi.org/10.1016/j.cbpb.2014.06.003

Adekunle HL, Sadiku SOE, Orire AM, others. 2012- Development of farm made floating feed for aquaculture species. International Journal of Advanced Biological Research 2, 579-583.

Bouvier J, Brisset A. 2006-Aquafeed twin screw extrusion processing. In: Asian Aquafeeds: Current developments in the aquaculture feed industry. Malaysian fisheries society occasional publication no. 13. Malaysian Fisheries Society, Kuala Lumpur, Malaysia, pp 76-104.

Erizal E, Lana M, Setyo AKR, Abbas B. 2016-Sintesis dan karakterisasi hidrogel superabsorben berbasis asam akrilat hasil iradiasi gamma. Jurnal Ilmiah Aplikasi Isotop dan Radiasi 11, 27-38.

FAO. 2017- Table 9. Type of formulated feed used for tilapia culture with advantage and disadvantage and the type of processing. In: Aquaculture Feed and Fertilizer Resources Information

Systemhttp://www.fao.org/fileadmin/user_upload/affris/img/Niletilapia_table/Nile_tila pia_table_9_01.pdf (accessed 15 September 2017).

FazeliNejad S, Ferreira JA, Brandberg T, Lennartsson PR, Taherzadeh MJ. 2016- Fungal protein and ethanol from lignocelluloses using Rhizopus pellets under simultaneous saccharification, filtration and fermentation (SSFF). Biofuel Research Journal 3, 372378. doi: 10.18331/BRJ2016.3.1.7

Ferreira JA, Lennartsson PR, Edebo L, Taherzadeh MJ. 2013-Zygomycetes-based biorefinery: Present status and future prospects. Bioresource Technologi 135, 523-532. doi: https://doi.org/10.1016/j.biortech.2012.09.064

Handoyo T, Morita N. 2006- Structural and functional properties of fermented soybean (Tempeh) by using Rhizopus oligosporus. International Journal of Food Properties 9, 347-355.

Kurniati T, Nurlaila L, Iim. 2017- Effect of inoculum dosage Aspergillus niger and Rhizopus oryzae mixture with fermentation time of oil seed cake (Jatropha curcas L) to the content of protein and crude fiber. Journal of Physics: Conference Series 824, 1-8.

Langeland M, Vidakovic A, Vielma J, Lindberg JE, Kiessling A, Lundh T. 2016Digestibility of microbial and mussel meal for Arctic charr (Salvelinus alpinus) and Eurasian perch (Perca fluviatilis). Aquaculture Nutrition 22, 485-495. doi: 10.1111/anu.12268 
Misra CK, Sahu NP, Jain KK. 2002- Effect of extrusion processing and steam pelleting diets on pellet durability, water absorption and physical response of Macrobrachium rosenbergii. Asian-Australasian Journal of Animal Science 15, 1354-1358.

Momoh AT, Abubakar MY, Ipinjolu JK. 2016- Effect of ingredients substitution on binding, water stability and floatation of farm-made fish feed. International Journal of Fisheriesand Aquatic Studies 4, 92-97.

Handoyo T, Morita N. 2006-Structural and functional properties of fermented soybean (Tempeh) by using Rhizopus oligosporus. International Journal of Food Properties 9, 347-355.

Niveditha VR, Sridhar KR. 2014- Antioxidant activity of raw, cooked and Rhizopus oligosporus fermented beans of Canavalia of coastal sand dunes of Southwest India. Journalof Food Science and Technology 51, 3253-3260.doi: 10.1007/s13197-0120830-9

Nurlaila. 2016- Hasil uji pakan ikan PT. Balqis Sejahtera. Laboratorium Penguji, Balai Bioteknologi, BPPT. Sertifikat hasil uji no. 142-SHU-07-2016, 13 Juli 2016

Olanipekun BF, Otunola ET, Adelakun OE, Oyelade OJ. 2009- Effect of fermentation with Rhizopus oligosporus on some physico-chemical properties of starch extracts from soybean flour. Food and Chemical Toxicology 47, 1401-1405. doi: https://doi.org/10.1016/j.fct.2009.02.023

Paolucci M, Fabbrocini A, Volpe MG, Varricchio E, Coccia E. 2012-Development of biopolymers as binders for feed for farmed aquatic organisms. In Aquaculture.InTech.https://cdn.intechopen.com/pdfs-wm/27101.pdf (accessed 02 October 2017).

Pradana Y, Sriherwanto C, Yunita E, Suja'i I. 2017- Growth of nile tilapia (Oreochormis niloticus) fry fed with coconut testa-cassava bagasse mixed substrate fermented by Rhizopus oryzae. Jurnal Bioteknologi \& Biosains Indonesia 4, 1-11.

Priatni S, Devi AF, Kardono LBS, Jayasena V. 2013- Quality and sensory evaluations of tempe prepared from various particle sizes of lupin beans. Jurnal Teknologi dan Industri Pangan 24, 209-214.

Sandhu KS, Punia S. 2017-Enhancement of bioactive compounds in barley cultivars by solid substrate fermentation. Journal of Food Measurement and Characterization1-7. doi: 10.1007/s11694-017-9513-6

Satari B, Karimi K, Taherzadeh MJ, Zamani A. 2016- Co-Production of fungal biomass derived constituents and ethanol from citrus wastes free sugars without auxiliary nutrients in airlift bioreactor. International Journal of Molecular Sciences 17, 1-12. doi: 10.3390/ijms17030302

Solomon SG, Ataguba GA, Abeje A. 2011- Water stability and floatation test of fish pellets using local starch sources and yeast (Saccahromyces cerevisae). International Journal of Latest Trends in Agriculture and Food Sciences 1, 1-4

Somerville C, Cohen M, Pantanella E, Stankus A, Lovatelli A. 2014- Fish in aquaponics. In: Small-scale aquaponic food production: integrated fish and plant farming, FAO Fisher. Food and Agriculture Organization of the United Nations, Rome, pp 103-121

Souza Filho PF, Zamani A, Taherzadeh MJ. 2017- Production of edible fungi from potato protein liquor (PPL) in airlift bioreactor. Fermentation 3, 1-12 doi:10.3390/fermentation3010012

Starzyńska-Janiszewska A, Stodolak B, Wikiera A. 2015- Proteolysis in tempeh-type products obtained with Rhizopus and Aspergillus strains from grass pea (Lathyrus sativus) seeds. Acta Sci Pol Technol Aliment 14:125-132. doi: 10.17306/J.AFS.2015.2.14 
Sutikno E, Nur A, Sony A. 2011- Pembuatan pelet apung skala rumah tangga dengan peralatan sederhana. In: Sudradjat A, Azwar Z, Supriyadi H, Rachmansyah, Sumiarsa G, Kristanto A, Imron, Parenrengi A, Insan I, Kusrini E (eds) Prosiding forum inovasi teknologi akuakultur. pusat penelitian dan pengembangan perikanan budidaya, Bali, Indonesia, pp 1095-1106

Umam RD, Sriherwanto C, Yunita E, Suja'i I. 2015- Growth of carp (Cyprinus carpio L.) fed with rice bran-coconut bagasse mixed substrate fermented using Rhizopus oryzae. Jurnal Bioteknologi \& Biosains Indonesia 2, 81-87.

Valdez-González F, Gutiérrez-Dorado R, Hernández-Llamas A, García-Ulloa M, SánchezMagaña L, Cuevas-Rodríguez B, Rodríguez-González H. 2017- Bioprocessing of common beans in diets for tilapia. In vivo digestibility and antinutritional factors.Journal of the Science of Food and Agriculture.doi: 10.1002/jsfa.8275

Vidakovic A, Langeland M, Sundh H, Sundell K, Olstorpe M, Vielma J, Kiessling A, Lundh T. 2016- Evaluation of growth performance and intestinal barrier function in Arctic Charr (Salvelinus alpinus) fed yeast (Saccharomyces cerevisiae), fungi (Rhizopus oryzae) and blue mussel (Mytilus edulis). Aquaculture Nutrition 22, 1348-1360. doi: 10.1111/anu.12344

Wronkowska M, Christa K, Ciska E, Soral-Śmietana M. 2015-Chemical characteristics and sensory evaluation of raw and roasted buckwheat groats fermented by Rhizopus oligosporus. Journal of Food Quality 38, 130-138. doi: 10.1111/jfq.12127 